eCommons@AKU

\title{
Low prevalence of the intact cag pathogenicity island in clinical isolates of Helicobacter pylori in Karachi, Pakistan
}

Javed Yakoob

Aga Khan University, javed.yakoob@aku.edu

Wasim Jafri

Aga Khan University, wasim.jafri@aku.edu

Zaigham Abbas

Aga Khan University, zaigham.abbas@aku.edu

Shahab Abid

Aga Khan University, shahab.abid@aku.edu

R. Khan

Aga Khan University

See next page for additional authors

Follow this and additional works at: https://ecommons.aku.edu/pakistan_fhs_mc_med_med Part of the Digestive System Diseases Commons, and the Gastroenterology Commons

\section{Recommended Citation}

Yakoob, J., Jafri, W., Abbas, Z., Abid, S., Khan, R., Jafri, N., Ahmad, Z. (2009). Low prevalence of the intact cag pathogenicity island in clinical isolates of Helicobacter pylori in Karachi, Pakistan. British Journal of Biomedical Science, 66(3), 137-142.

Available at: https://ecommons.aku.edu/pakistan_fhs_mc_med_med/155 
Authors

Javed Yakoob, Wasim Jafri, Zaigham Abbas, Shahab Abid, R. Khan, N. Jafri, and Z. Ahmad 


\title{
Low prevalence of the intact cag pathogenicity island in clinical isolates of Helicobacter pylori in Karachi, Pakistan
}

\author{
J. Yakoob, W. Jafri, Z. Abbas, S. Abid, R. Khan, N. Jafri \& Z. Ahmad
}

To cite this article: J. Yakoob, W. Jafri, Z. Abbas, S. Abid, R. Khan, N. Jafri \& Z. Ahmad (2009) Low prevalence of the intact cag pathogenicity island in clinical isolates of Helicobacter pylori in Karachi, Pakistan, British Journal of Biomedical Science, 66:3, 137-142, DOI:

10.1080/09674845.2009.11730260

To link to this article: https://doi.org/10.1080/09674845.2009.11730260

曲 Published online: 23 May 2016.

Submit your article to this journal $־$

Џ Article views: 3

Citing articles: 5 View citing articles $\longleftarrow$ 


\section{Low prevalence of the intact cag pathogenicity island in clinical isolates of Helicobacter pylori in Karachi, Pakistan}

\author{
J. YAKOOB, W. JAFRI, Z. ABBAS, S. ABID, R. KHAN, \\ N. JAFRI and Z. AHMAD* \\ Departments of Medicine and "Pathology, The Aga Khan University, \\ Karachi, Pakistan
}

\section{Accepted: 29 May 2009}

\section{Introduction}

Helicobacter pylori is a Gram-negative microaerophilic bacterium that infects human gastric mucosa and is recognised as a major cause of chronic active gastritis, peptic ulcer disease, gastric adenocarcinoma and gastric mucosaassociated lymphoid tissue lymphoma. ${ }^{1,2}$ It also has a relationships with gastro-oesophageal reflux disease and adenocarcinoma of the gastric cardia. ${ }^{3}$ It is a class I carcinogen that colonises the human stomach of more than $50 \%$ of the world's population. However, only a small subset of infected people experience $H$. pylori-associated illnesses.

Although the pathogenesis of H. pylori infection is not well understood, there are several virulence factors that may contribute to mucosal damage. The cagA gene is conventionally used as a marker of pathogenic strains. However, the literature suggests that the cagA gene alone is not a suitable marker of $H$. pylori virulence. A strong predictor of severe disease outcome is infection with a bacterial strain harbouring the cag pathogenicity island (cag-PAI), a $40 \mathrm{~kb}$ segment of DNA. ${ }^{4}$

$H$. pylori cag-PAI is horizontally acquired and follows free recombinations within the species. The chromosomal integrity of this island, or the lack thereof, is thought to play an important role in the progress of the gastroduodenal pathology caused by H. pylori. These genes encode a type IV secretion system that forms a syringe-like structure to translocate the immunodominant cagA protein into the gastric epithelial cells. ${ }^{5}$ cag-PAI has also been implicated in the induction of interleukin-8 (IL-8) in cultured gastric cells. ${ }^{6}$

At least 17 out of 27 genes were found to be essential for translocation of cagA into host cells (syringe-like function), and 14 were required to fully induce transcription of IL-8. ${ }^{6}$ The cag-PAI and vacuolating toxin A (vacA) gene are located far apart on the chromosome, but there is a statistical linkage between presence of the cag-PAI and the s1 genotype of

\section{ABSTRACT}

Clinical diseases that follow Helicobacter pylori infection are associated with expression of the cagA gene, a part of cytotoxin-associated gene pathogenicity island (cag-PAI). This study aims to determined whether or not the presence of cagA is associated with the presence of complete cag-PAI and to evaluate inflammatory changes associated with the five loci in the cag-PAI of $H$. pylori comprising cagA, cagA promoter region (cagAP), $\operatorname{cag} \mathrm{E}, \operatorname{cag} \mathrm{T}$ and the left end of the cagA gene (LEC). H. pylori isolates were obtained from patients with dyspeptic symptoms. Clinical strains of $H$. pylori were screened by the polymerase chain reaction (PCR) for respective genes of the cag-PAI. Of $115 \mathrm{H}$. pylori isolates, $31(28 \%)$ were positive for the five cag-PAI loci. $H$. pylori isolates with intact cag-PAI were associated with gastric carcinoma (GC; $n=9[60 \%])$ and gastric ulcer (GU; $n=5[45 \%])$ compared to non-ulcer dyspepsia (NUD; $n=14[18 \%])(P=0.001$ and $P=0.049$, respectively). In patients with intact cag-PAI, acute on chronic inflammation was present in $25(81 \%)$ and was more common than chronic inflammation $(P=0.013)$. The cag $\mathrm{E}$ and cagAP had deletions in $25(37 \%)$ and $23(35 \%)$ cases, respectively. The cagAP region was significantly associated with GC $(n=12[80 \%], P<0.001)$ and GU $(n=9[82 \%]$, $P=0.001)$ compared to NUD $(n=24[30 \%]$ and with significant acute on chronic inflammation $(n=40[80 \%]$, $P=0.007)$. The distribution of vacAs1a with intact cag-PAI in GC was $9(60 \%)$ and in NUD was $10(13 \%)(P<0.001)$. The presence of the cagA gene does not signify presence of an intact cag-PAI. Most of the H. pylori isolates studied had partial cag-PAI with missing cagE and cagA promoter regions.

KEY WORDS: Duodenal ulcer.

Genes.

Genomic islands.

Helicobacter pylori.

Non-ulcer dyspepsia.

vacA. ${ }^{7}$ Strains with this genotype are called type I strains and are generally more virulent than type II strains that lack the cag-PAI and harbour the less virulent vacA s2 genotype. ${ }^{8}$

The aim of this study is to determine the association of cagA with intact cag-PAI to evaluate inflammatory changes associated with intact cag-PAI and determine any association between cag-PAI and the vacA allele s1. The completeness of cag-PAI is determined using specific flanking polymerase chain reaction (PCR) primers from five loci in the $H$. pylori cag-PAI comprising cagA, cagA promoter region (cagAP), 
cagE, cagT and the left end of the cag-PAI (LEC) in clinical isolates of $H$. pylori. The absence of cag-PAI is detected by the PCR for the cag empty site flanking the left and right ends of the cag-PAI indicating that they truly lacked the cagA gene. ${ }^{9}$

\section{Materials and methods}

\section{Patients and $\mathrm{H}$. pylori strains}

A total of $115 \mathrm{H}$. pylori isolates were obtained from patients undergoing gastroscopy and gastric biopsy for dyspeptic symptoms attending the endoscopy suite of the gastroenterology department at the Aga Khan University from July 2005 to December 2007 (Table 1). Mean age was $40 \pm 14$ years (range: 18-78 years). Informed consent was obtained for oesophagogastroduodenoscopy (EGD) and biopsy from the antrum and body of the stomach. The study was approved by the institution's ethics review committee.

Sterilised biopsy forceps were used to obtain gastric biopsy specimens from an area of inflammation for rapid urease test, histopathology, cag-PAI-associated virulence genes, cagA empty site and vacA PCR.

After primary isolation and identification of the gastric organisms as $\mathrm{H}$. pylori, the strains were frozen at $-70^{\circ} \mathrm{C}$ until their use in the study. Subsequently, bacteria were cultured on Columbia blood agar (Oxoid) plates containing 7\% sheep blood for $3-5$ days at $37^{\circ} \mathrm{C}$ under microaerobic conditions using Campygen strips in anaerobic jars (Oxoid).

Several small, rounded colonies were picked from different parts of the culture plate and subcultured twice to obtain a pure culture. Gram's stain, urease and catalase tests were used to confirm identification and to exclude the possibility of contamination.

H. pylori cells were harvested from plates by suspension in 2-mL sterile phosphate-buffered saline (PBS) and were pelleted by centrifugation at $3000 \mathrm{xg}$ for $20 \mathrm{~min}$. The clinical symptoms at the time of presentation, diagnosis, drug treatment dosage and duration were noted, together with endoscopy findings.

\section{Rapid urease test}

Pronto Dry, a commercial rapid urease test (Medical Instrument Corp., France), results were read in 30 min after sampling, in accordance with the manufacturer's instructions. Colour change from yellow to pink was indicative of a positive reaction. ${ }^{10}$

\section{Histopathology}

Gastric antral biopsy specimens stained with haematoxylin and eosin (H\&E) were examined by a pathologist unaware of the patient's clinical diagnosis. In doubtful cases, Giemsa staining was performed to ascertain the presence of $H$. pylori. Degree of gastritis on H\&E stain was scored in accordance with the Sydney system ${ }^{11}$ for the level of inflammation and neutrophil infiltration $(0=$ none, $1=$ mild, $2=$ moderate, $3=$ severe).

\section{Extraction of genomic DNA}

DNA was extracted from confluent cultures with fewer than three in vitro passages. ${ }^{12}$ The bacterial cells from a chocolate agar plate were washed (x2) with PBS and centrifuged at $3000 \mathrm{xg}$ for $20 \mathrm{~min}$. H. pylori DNA was extracted by a modified phenol/chloroform method..$^{13}$ Briefly, a bacterial
Table 1. Demographic and clinical findings of patients $(n=115)$.

\begin{tabular}{|c|c|c|}
\hline Gender & Male: Female & $77: 38$ \\
\hline \multirow[t]{2}{*}{ Age } & Range & 18-78 years \\
\hline & Mean age \pm SD & $40 \pm 14$ years \\
\hline \multirow[t]{3}{*}{ Symptoms } & Abdominal pain & $92(82 \%)$ \\
\hline & Vomiting & $13(10 \%)$ \\
\hline & Weight loss & $10(8 \%)$ \\
\hline \multirow[t]{4}{*}{ Diagnosis } & Non-ulcer dyspepsia & 79 (69\%) \\
\hline & Gastric ulcer & $11(9 \%)$ \\
\hline & Gastric carcinoma & $15(13 \%)$ \\
\hline & Duodenal ulcer & $10(9 \%)$ \\
\hline \multirow[t]{3}{*}{ Histopathology } & Acute inflammation & $10(9 \%)$ \\
\hline & Chronic inflammation & 19 (16\%) \\
\hline & Acute on chronic inflammation & $86(75 \%)$ \\
\hline
\end{tabular}

pellet was resuspended in Tris- $\mathrm{HCl}$ buffer containing ethylenediaminetetraacetate (TE, $\mathrm{pH} 8.0)$ and lysozyme (30 $\mathrm{mg} / \mathrm{mL}$ ) and was incubated at $37^{\circ} \mathrm{C}$ for $30 \mathrm{~min}$. The suspension was treated with sodium dodecyl sulphate (SDS, $10 \%)$, proteinase $\mathrm{K}(2.5 \mathrm{mg} / \mathrm{mL})$ and RNase A $(40 \mathrm{mg} / \mathrm{mL})$. DNA was extracted with phenol/chloroform/isoamyl alcohol, precipitated by sodium acetate and ice-cold absolute alcohol, and washed with ice-cold alcohol (70\%). The DNA pellet was finally resuspended in TE buffer. DNA content and purity were determined by measuring absorbance at $260 \mathrm{~nm}$ and $280 \mathrm{~nm}$ using a spectrophotometer (Beckman DU-600, USA).

\section{cag-PAI PCR analysis}

The PCR analyses were carried out with oligonucleotide pairs (Table $2 \mathrm{~A}$ ), as described previously, ${ }^{14}$ to amplify five different loci spread over the cag I and cag II regions. cagA, the cag $\mathrm{A}$ promoter region and $c a g \mathrm{E}$ represented $\operatorname{cagI}$, while the left end of cag (LEC) and cagT were selected to represent cagII.

Pairs of oligonucleotide primers were used to detect the presence of the cag-PAI genes (cagA, the cagAP region, $c a g \mathrm{E}$, cag $\mathrm{T}$ and the LEC, containing both inside and outside genes of cag-PAI). These primer pairs were designed on the basis of published sequences. ${ }^{4,9,15}$ To test for the absence of the cag-PAI, PCR for the cag empty-site was used with primers that flanked the left and right ends of the cag-PAI. ${ }^{9}$

H. pylori strains ATCC 43526 and ATCC 43504, which have been determined to have the entire cag-PAI, were used as positive controls, and ATCC 51932 was used as a negative control as it lacks cagA. Amplification specificity for the different loci was assessed by testing $H$. pylori strains ATCC 43526, ATCC 43504 and ATCC 51932 with each experiment. Amplification by PCR was performed in $25-\mu \mathrm{L}$ volumes containing $10 \mathrm{mmol} / \mathrm{L}$ Tris- $\mathrm{HCl}$ (pH 8.3), $50 \mathrm{mmol} / \mathrm{L}$ $\mathrm{KCl}, 1.5-2.5 \mathrm{mmol} / \mathrm{L} \mathrm{MgCl}_{2}, 200 \mu \mathrm{mol} / \mathrm{L}$ deoxynucleoside triphosphates, 2 units Thermus aquaticus (Taq) DNA polymerase (Promega) and $25 \mathrm{\rho mol}$ both forward and reverse primers (synthesised using an MWG automatic synthesiser). The total volume was made up with doubledistilled water (DDW).

Amplification was performed in a Perkin Elmer 9700 thermal cycler (Applied Biosystems). The cycles comprised 
Table 2A. Sequences and locations of oligonucleotide primers.

\begin{tabular}{|c|c|c|c|}
\hline Primer & Primer sequence & Amplicon (bp) & Location $^{a}$ \\
\hline cagA-F1 & 5'-AACAGGACAAGTAGCTAGCC-3' & 349 & $2700-2719^{*}$ \\
\hline cagA-R1 & 5'-TATTAATGCGTGTGTGGCTG-3' & & $3400-3381^{*}$ \\
\hline cagA-F2 & 5'-GATAACAGGCAAGCTाTTGA-3' & 701 & $157-176^{*}$ \\
\hline cagA-R2 & 5'-CTGCAAAAGATTGTTTGGCAGA-3' & & $505-484^{*}$ \\
\hline cagE-F1 & 5'-GCGATTGTTATTGTGCTTGTAG-3' & 329 & $16,891-16,870^{\dagger}$ \\
\hline cagE-R1 & 5'-GAAGTGGTTAAAAAATCAATGCCCC-3' & & $16,563-16,587^{\dagger}$ \\
\hline cagT-F1 & 5'-CCATGTTTATACGCCTGTGT-3' & 301 & $442-461^{\dagger}$ \\
\hline cagT-R1 & 5'-CATCACCACACCC ПITGAT-3' & & $723-742^{\dagger}$ \\
\hline LEC-F1 & 5'-ACATITTGGCTAAATAAACGCTG-3' & 384 & $3920-3942^{\ddagger}$ \\
\hline LEC-R1 & 5'-TCTCCATGTTGCCATTATGCT-3' & & $4303-4283^{\ddagger}$ \\
\hline LEC-F2 & 5'-ATAGCGTITTGTGCATAGAA-3' & 877 & $3856-3875^{\ddagger}$ \\
\hline LEC-R2 & 5'-ATCTITAGTCTCTITAGCTा-3' & & $4732-4713^{\ddagger}$ \\
\hline cagAP-F1 & 5'-GTGGGTAAAAATGTGAATCG-3' & 730 & $18,738-18,757^{\dagger}$ \\
\hline cagAP-R1 & 5'-CTGCAAAAGATTGTाTGGCAGA-3' & & $505-484^{*}$ \\
\hline cagAP-F2 & 5'-CTACTTGTСССААССАПТा-3' & 1181 & $18,495-18,514^{\dagger}$ \\
\hline cagAP-R2 & 5'-CTGCAAAAGATTGTTTGGCAGA-3' & & $505-484^{*}$ \\
\hline cagA empty site ${ }^{\S}$ & & 360 & \\
\hline 2 & 5'-ACATITTGGCTAAATAAACGCTG-3' & & \\
\hline 25 & 5'-TCATGCGAGCGGCGATGTG-3' & & \\
\hline
\end{tabular}

an initial denaturation of target DNA at $94^{\circ} \mathrm{C}$ for 5 min and then denaturation at $94^{\circ} \mathrm{C}$ for $1 \mathrm{~min}$, primer annealing at $55^{\circ} \mathrm{C}$ for $1 \mathrm{~min}$ and extension at $72^{\circ} \mathrm{C}$ for $1 \mathrm{~min}$. The final cycle included an extension step for $7 \mathrm{~min}$ at $72^{\circ} \mathrm{C}$ to ensure full extension of the product. Samples were amplified through 35 consecutive cycles.

The amplified products were resolved on $2 \%$ agarose gel in $1 \times$ TAE buffer $(40 \mathrm{mmol} / \mathrm{L}$ Tris-acetate, $1 \mathrm{mmol} / \mathrm{L}$ EDTA [pH 8.0]) containing ethidium bromide $(0.5 \mu \mathrm{g} / \mathrm{mL})$ and then visualised under ultraviolet (UV) light.

\section{vacA PCR analysis}

Amplification of vacA alleles by PCR was performed in a $25 \mu \mathrm{L}$ volume containing $10 \mathrm{mmol} / \mathrm{L}$ Tris- $\mathrm{HCl}$ (pH 8.3), $50 \mathrm{mmol} / \mathrm{L}$ $\mathrm{KCl}, 1.5-2.5 \mathrm{mmol} / \mathrm{L} \mathrm{MgCl}_{2}, 200 \mu \mathrm{mol} / \mathrm{L}$ deoxynucleoside triphosphates, 2 units Taq DNA polymerase (Promega) and $25 \mu \mathrm{mol}$ forward and reverse primers (synthesised by an MWG automatic synthesiser) (Table 2B). ${ }^{16}$

The amplification cycle for vacA alleles consisted of an initial denaturation of target DNA at $95^{\circ} \mathrm{C}$ for $5 \mathrm{~min}$ and than denaturation at $95^{\circ} \mathrm{C}$ for $1 \mathrm{~min}$, primer annealing at $52^{\circ} \mathrm{C}$ for $1 \mathrm{~min}$ and an extension at $72^{\circ} \mathrm{C}$ for $1 \mathrm{~min}$. The final cycle included an extension step for $7 \mathrm{~min}$ at $72^{\circ} \mathrm{C}$ to ensure full extension of the product. Samples were amplified through 35 consecutive cycles.

Positive and negative reagent controls were performed with each batch of amplifications. DNA from $H$. pylori strains ATCC 43504 (vacAs1am1, cagA-positive), ATCC 51932 (vacA s2m2, cagA-negative) and ATCC 43526 (vacAs1bm1, cagApositive) was used to define the accuracy of the vacA PCR.

Table 2B. Oligonucleotide primers used in typing of $H$. pylori vacA alleles.

\begin{tabular}{llll}
\hline Region amplified & Primer & Primer sequence & Size and location of PCR product \\
\hline $\mathrm{m} 1$ & VA3-F & 5'-GGTCAAAATGCGGTCATGG-3' & 290 bp (2741-3030) \\
\hline VA3-R & 5'-CCATTGGTACCTGTAGAAAC-3' & \\
\hline VA4-F & 5'-GGAGCCCCAGGAAACATTG-3' & 352 bp (976-1327) \\
\hline S1a & VA4-R & 5'-CATAACTAGCGCCTTGCAC-3' & \\
\hline SS1-F & 5'-GTCAGCATCACACCGCAAC-3' & 190 bp (866-1055) \\
\hline & VA1-R & 5'-CTGCTTGATGCGCCAAAC-3' & \\
\hline
\end{tabular}

a. Location in published cagA sequence (ref. 14).

b. Location in published vacA sequence (ref. 16). 


\section{Statistical assessment}

The Statistical Package for Social Science SPSS (Release 11.5, standard version, SPSS; 1989-99) was used for data analysis. Descriptive analysis was performed for demographic and clinical features. Results were presented as mean \pm SD for quantitative variables and number (\%) for qualitative variables. Differences in proportion were assessed using Pearson's $\chi^{2}$ test, Fisher's exact or likelihood ratio test, where appropriate. $P<0.05$ was considered significant.

\section{Results}

The clinical features and diagnosis of patients included in the study are given in Table 1. Partial deletions involved cag I and cag II regions of the cag-PAI equally. In isolates from NUD, deletions of cag-PAI genes were more frequent (Table 3A). These deletions predominantly involved cagE and cagA promoter region of the cag-PAI (Table 3B). The product corresponding to the cagA empty site was obtained from five patients with partially intact cagA PAI, indicating that they had mixed infections (i.e., a mixture of $H$. pylori strains with and without the cagA gene).

\section{Presence of cag-PAI genes}

The cagA gene was positive in $66(57 \%)$, cagA LEC in 63 $(55 \%)$, cagAT in $63(55 \%)$, cagAP region in $50(43 \%)$ and cagAE

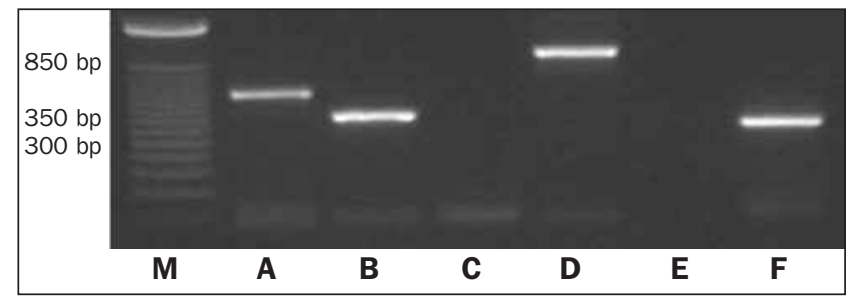

Fig. 1. Distribution of cag-PAl gene amplified products in patients with non-ulcer dyspepsia. Lane M: molecular weight marker $50 \mathrm{bp}$ (Promega); Lane A and B: cagA gene present; Lane C: cagA promoter absent; Lane D: LEC present; Lane E: cagE absent; Lane F: cagT present.

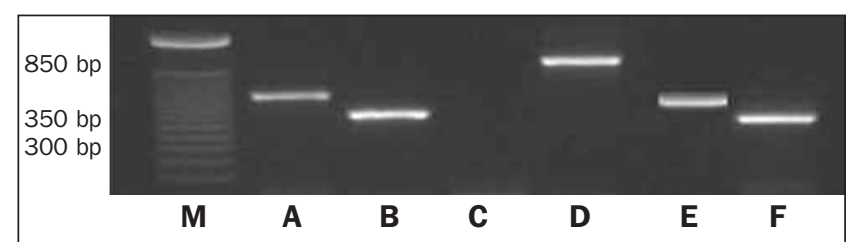

Fig. 2. Distribution of cag-PAl gene amplified products in patients with duodenal ulcer. Lane M: molecular weight marker 50 bp (Promega); Lane A and B: cagA gene present; Lane C: cagA promoter absent; Lane D: LEC present; Lane E: cagE present; Lane F: cagT present.

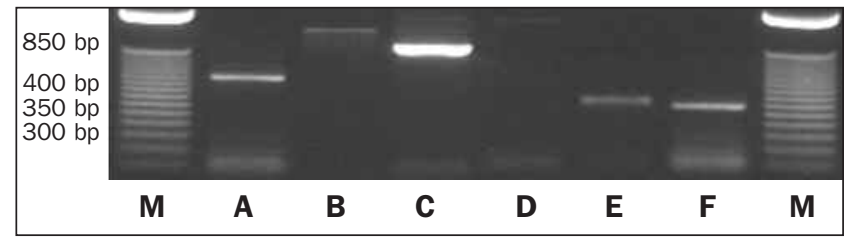

Fig. 3. Distribution of cag-PAI gene amplified products in patients with gastric carcinoma. Lane M: molecular weight marker 50 bp (Promega); Lane A: cagA gene; Lane B: cagA promoter; Lane C: LEC; Lane D: negative control; Lane E: cagE; Lane F: cagAT.
Table 3A. Correlation of cagPAl with diagnosis and histopathology.

\begin{tabular}{|c|c|c|c|}
\hline & \multicolumn{3}{|c|}{ cagPAI } \\
\hline & $\begin{array}{c}\text { Intact } \\
n(\%) \\
31(28)\end{array}$ & $\begin{array}{c}\text { Partial } \\
n(\%) \\
42(36)\end{array}$ & $\begin{array}{c}\text { Deleted } \\
n(\%) \\
42(36)\end{array}$ \\
\hline \multicolumn{4}{|l|}{ Diagnosis } \\
\hline Non-ulcer dyspepsia & $14(18)$ & $28(35)$ & $37(47)$ \\
\hline Gastric ulcer & $5(45)$ & $6(55)$ & 0 \\
\hline Gastric carcinoma & $9(60)$ & $5(33)$ & $1(7)$ \\
\hline Duodenal ulcer & $3(30)$ & $3(30)$ & $4(40)$ \\
\hline \multicolumn{4}{|l|}{ Histopathology } \\
\hline \multicolumn{4}{|l|}{ Inflammation } \\
\hline Acute inflammation & $5(50)$ & $3(30)$ & $2(20)$ \\
\hline Chronic inflammation & 1(5) & $12(63)$ & $6(32)$ \\
\hline Acute on chronic inflammation & $25(29)$ & $27(31)$ & $34(39)$ \\
\hline \multicolumn{4}{|l|}{ Lymphoid aggregates } \\
\hline Positive & $26(31)$ & $26(34)$ & $30(35)$ \\
\hline Negative & $5(17)$ & $13(43)$ & $12(40)$ \\
\hline \multicolumn{4}{|l|}{ Neutrophil infiltration } \\
\hline Mild & $1(7)$ & $7(50)$ & $6(43)$ \\
\hline Moderate & $25(30)$ & $27(33)$ & $30(37)$ \\
\hline Severe & $5(26)$ & $8(42)$ & $6(32)$ \\
\hline
\end{tabular}

in $48(42 \%) H$. pylori isolates. In $31(28 \%)$ isolates cag-PAI was intact, it had partial deletions with some genes missing in $42(36 \%)$, and was completely deleted in $42(36 \%)$. Deletions were present in cagE $(n=23$ [37\%], $P<0.001)$ and in cagAP (23 [35\%], $P<0.001)$ (Figs. 1 and 2).

Associations of cag-PAI genes with gastroduodenal disorders Association of $H$. pylori isolates with intact cag-PAI was seen in GC $(n=9[60 \%])$, GU $(n=5[45 \%])$ and NUD $(n=14[18 \%])$ (Table 3A, Fig. 3). The cagA gene was associated with GU $(n=9[82 \%])$ and GC $(n=14[93 \%])$, compared to NUD $(n=38[48 \%])(P=0.049$ and $P=0.001$, respectively). The cagAP region was significantly associated with GC $(n=14[93 \%]$, $P<0.001)$, GU $(n=9[82 \%], P=0.001)$ and DU $(n=7[70 \%]$, $P=0.016)$ compared to NUD $(n=24[30 \%])$. cagA LEC was associated with GU $(n=11[100 \%])$ and GC $(n=13[87 \%])$ compared to NUD $(n=40[51 \%]) \quad(P<0.001$ and $P=0.010$, respectively). cagA LEC was also associated with GU $(n=11[100 \%])$ compared to DU $(n=5[50 \%])(P=0.002)$ and GC $(n=13[87 \%])$ compared to DU $(n=5[50 \%])(P=0.045)$. cagE was associated with GU $(n=7[64 \%], P=0.043)$ and GC $(n=13[87 \%], P<0.001)$ compared to NUD $(n=25[32 \%])$. cagT was associated with GU $(n=10[91 \%], P=0.006)$ and GC $(n=14[93 \%], P=0.002)$ compared to NUD $(n=40[51 \%])$.

\section{Associations of cag-PAI genes with histology}

In patients infected with $H$. pylori with intact cag-PAI, acute on chronic inflammation was present in $25(81 \%)(P=0.013$, Table $3 \mathrm{~A})$. In these patients, acute on chronic inflammation was more common than chronic inflammation $(P=0.014)$, and cagAP ( $n=40[47 \%], P=0.007)$ was associated with acute on chronic inflammation. Intestinal metaplasia was present in four $(57 \%)$ isolates with intact cag-PAI $(P=0.082)$. 
Table 3B. Distribution of cag-PAl genes in the clinical isolates

\begin{tabular}{llccc} 
& & & & \\
& & Intact & Partial & Deleted \\
& & $n(\%)$ & $n(\%)$ & $n(\%)$ \\
& & $31(28)$ & $42(36)$ & $42(36)$ \\
\hline cagA & Positive & $31(46)$ & $35(52)$ & $0(0)$ \\
\hline cagAP & Negative & $0(0)$ & $7(14)$ & $40(86)$ \\
\hline cagLEC & Positive & $31(62)$ & $19(38)$ & $0(0)$ \\
\hline cagE & Negative & $0(0)$ & $23(35)$ & $42(65)$ \\
\hline cagT & Positive & $31(48)$ & $32(49)$ & $0(0)$ \\
& Negative & $0(0)$ & $10(19)$ & $42(81)$ \\
\hline cagA empty site & Positive & $31(65)$ & $17(35)$ & $0(0)$ \\
& Pegative & $0(0)$ & $23(37)$ & $42(63)$ \\
\hline & Positive & $31(49)$ & $32(51)$ & $0(0)$ \\
\hline & Negative & $31(45)$ & $37(54)$ & $1(1)$ \\
\hline
\end{tabular}

cagAP: cagA promoter region; LEC: left end of cag-PAl.

\section{Associations of cag-PAI genes with vacAs1a and $m 1$}

The presence of vacAs1a was seen in $80(70 \%)$ isolates and that of vacAm1 was seen in $64(56 \%)$. Distribution of vacAs1a with intact cag-PAI was GC $(n=11[73 \%])$, NUD $(n=10[13 \%]$, $P<0.001), \mathrm{GU}(n=4[36 \%], P=0.05)$ and DU $(n=3[30 \%]$ $P=0.03$ ). It was associated with acute inflammation in three $(30 \%)$ cases and acute on chronic inflammation in $20(23 \%)$ $(P=0.164)$. Distribution of vacAm1 with intact cag-PAI was GC $(n=8[53 \%])$, DU $(n=3[30 \%])$ and GU $(n=3[27 \%])$ compared to NUD $(n=5[6 \%])(P<0.001, P=0.038, P=0.050$, respectively). Acute on chronic inflammation was more frequent $(n=16[19 \%])$ than chronic inflammation $(P=0.008)$.

\section{Discussion}

The epidemiology of $H$. pylori infection remains important in public health because of its high prevalence and its association with gastric cancer and lymphoma. The seroprevalence of $H$. pylori in the adult population of Pakistan is reported as $58 \% .^{18} \mathrm{~A}$ recent study revealed early colonisation/infection of infants with $H$. pylori and a prevalence of $67 \%$ at nine months of age in a peri-urban community in Karachi, Pakistan. ${ }^{19}$

In the present study, $H$. pylori isolates from patients with NUD constituted the majority, which reflects the high numbers in this group attending the gastroenterology clinic and having endoscopy. H. pylori isolates with intact cag-PAI were associated with GC, GU and DU and on histopathology with acute and acute on chronic inflammation. cagA gene, cag AP region, cagLEC, cagE and cagT were all associated with GC, GU and DU compared to NUD.

H. pylori isolates from NUD lacked the cagAP region and cagE (Fig. 1) while they were intact in those from GC (Fig. 2). There was a significant difference in inflammatory infiltration of the gastric mucosa between patients with intact cag-PAI and those with partial cag-PAI type strains (Table 3A). These findings suggest that the strains with partial cag-PAI have less ability to cause inflammation than those with intact cag-PAI.

The implications of the present study are that cag-PAI is partially intact in the majority of our clinical isolates. This is consistent with a previous study in which cag-PAI appeared

Table 4. Relationship between intact cag-PAl and vacA subtypes in $H$. pylori strains.

\begin{tabular}{|c|c|c|c|c|c|c|}
\hline & \multicolumn{3}{|c|}{ cag-PAI s1a } & \multicolumn{3}{|c|}{ cag-PAI m1 } \\
\hline & $\begin{array}{c}\text { Positive } \\
n(\%)\end{array}$ & $\begin{array}{c}\text { Negative } \\
n(\%)\end{array}$ & $P$ value & $\begin{array}{c}\text { Positive } \\
n(\%)\end{array}$ & $\begin{array}{c}\text { Negative } \\
n(\%)\end{array}$ & $P$ value \\
\hline \multicolumn{7}{|l|}{ Diagnosis } \\
\hline Non-ulcer dyspepsia & 10(13) & $69(87)$ & 0.002 & $5(6)$ & 74(94) & $<0.001$ \\
\hline Gastric ulcer & $3(27)$ & $8(73)$ & & $3(27)$ & $8(73)$ & \\
\hline Duodenal ulcer & $2(20)$ & $8(80)$ & & $3(30)$ & $7(70)$ & \\
\hline Gastric carcinoma & $9(60)$ & $6(40)$ & & $8(53)$ & $7(47)$ & \\
\hline \multicolumn{7}{|l|}{ Histopathology } \\
\hline \multicolumn{7}{|l|}{ Inflammation } \\
\hline Acute & $3(30)$ & $7(70)$ & 0.164 & $3(30)$ & $7(70)$ & 0.016 \\
\hline Chronic & $1(5)$ & 18(95) & & $0(0)$ & 19(100) & \\
\hline Acute on chronic & $20(23)$ & $66(77)$ & & 16(19) & $70(81)$ & \\
\hline \multicolumn{7}{|l|}{ Lymphoid aggregates } \\
\hline Positive & $20(23)$ & $65(77)$ & 0.237 & $3(10)$ & $27(90)$ & 0.243 \\
\hline Negative & $4(13)$ & $26(87)$ & & 16(19) & $69(81)$ & \\
\hline \multicolumn{7}{|l|}{ Neutrophil infiltration } \\
\hline Mild & $1(7)$ & 13(93) & 0.302 & $\mathrm{O}(0)$ & $14(100)$ & 0.011 \\
\hline Moderate & $18(22)$ & $64(78)$ & & $18(22)$ & $64(78)$ & \\
\hline Severe & $5(26)$ & $14(74)$ & & $1(5)$ & 18(95) & \\
\hline
\end{tabular}


to be partial in the majority of clinical isolates around the world. ${ }^{19}$ Only $12 \%$ of the Indian isolates carried an intact cag-PAI. Deletion frequencies of cagA, cagE, and $\operatorname{cag} \mathrm{T}$ genes were higher in benign cases than in isolates from severe ulcers and gastric cancer. ${ }^{19}$

In contrast, another study from Calcutta, India, showed that $80-90 \%$ of Calcutta strains carried cag-PAI and the potentially toxigenic vacAs1 alleles of vacA, independently of disease status. ${ }^{20}$ In the present study, the clinical outcome of $H$. pylori infection was predicted by analysing genes of the cag-PAI, with the cagAP region and cag $\mathrm{E}$ more commonly associated with GC and GU compared to NUD, which is consistent with a previous study. ${ }^{21}$

Jenks et al. described the presence of $c a g \mathrm{E}$ and correlated it with that of cagA. ${ }^{22}$ However, in the present study it was associated with the cagA promoter region. Also, the majority of partial deletions of cag-PAI were observed in cagE, followed by the cagAP region.

The cagA gene promoter region appeared to be a better marker of $H$. pylori virulence; however, it is known for the diversity of its sequences in isolates. The cagE gene, which is consistently retained near the cagAP region, appeared to be a better substitute for the cagAP region. Also, cagE gene PCR can be used to screen the cag-PAI structure, as suggested previously. ${ }^{22}$

An association was noted between vacAs1a and vacAm1, with intact cag-PAI. In the present study, vacAs1 with intact cag-PAI was associated with GC, GU and DU. This is in keeping with a previous study that showed vacAs1 occurs significantly more often in isolates from patients with peptic ulceration or gastric adenocarcinoma, while vacAs2 invariably occurs in patients with gastritis alone. ${ }^{23}$

A shortcoming of the present study is the small number of patients in the different groups. The study, however, is ongoing but the results presented here indicate that the presence of the cagA gene does not signify the presence of an intact cag-PAI, as most of the H. pylori isolates had partial cag-PAI with missing cagE and cagAP regions.

This work was supported by an Aga Khan University Research Grant SM $100327^{*} 11431$ to JY. The authors are grateful to staff at the Juma Research Building, The Aga Khan University, for their assistance during this work.

\section{References}

1 Blaser MJ. Ecology of Helicobacter pylori in the human stomach. J Clin Invest 1997; 100: 759-62.

2 Blaser MJ, Perez-Perez GI, Kleanthous $\mathrm{H}$ et al. Infection with Helicobacter pylori strains possessing cagA is associated with an increased risk of developing adenocarcinoma of the stomach. Cancer Res 1995, 55: 2111-5.

3 Cover TL, Blaser MJ. Helicobacter pylori factors associated with disease. Gastroenterology 1999; 117: 257-61.

4 Censini S, Lange C, Xiang Z et al. Cag pathogenicity island of Helicobacter pylori encodes type-specific and disease-associated virulence factors. Proc Natl Acad Sci USA 1996; 93: 14648-53.

5 Karnholz A, Hoefler C, Odenbreit S, Fischer W, Hofreuter D, Haas R. Functional and topological characterization of novel components of the comB DNA transformation competence system in Helicobacter pylori. J Bacteriol 2006; 188: 882-93.
6 Fischer W, Jürgen PL, Buhrdorf R, Gebert B, Odenbreit S, Haas R. Systematic mutagenesis of the Helicobacter pylori cag pathogenicity island: essential genes for cagA translocation in host cells and induction of interleukin-8. Mol Microbiol 2001; 42: 1337-48.

7 van Doorn LJ, Figueiredo C, Sanna R, Blaser MJ, Quint WG. Distinct variants of Helicobacter pylori cagA are associated with vacA subtypes. J Clin Microbiol 1999; 37: 2306-11.

8 Xiang Z, Censini S, Bayeli PF et al. Analysis of expression of CagA and VacA virulence factors in 43 strains of Helicobacter pylori reveal that clinical isolates can be divided into two major types and that cagA is not necessary for expression of the vacuolating cytotoxin. Infect Immun 1995; 63: 94-8.

9 Akopyants NS, Clifton SW, Kersulyte D et al. Analyses of the cag pathogenicity island of Helicobacter pylori. Mol Microbiol 1998; 28: 37-53.

10 Said RM, Cheah PL, Chin SC, Goh KL. Evaluation of a new biopsy urease test: Pronto Dry for the diagnosis of Helicobacter pylori infection. Eur J Gastroenterol Hepatol 2004; 16: 195-9.

11 Price AB. The Sydney System: histological division. J Gastroenterol Hepatol 1991; 6: 209-22.

12 Matteo MJ, Granados G, Pérez CV, Olmos M, Sanchez C, Catalano M. Helicobacter pylori cag pathogenicity island genotype diversity within the gastric niche of a single host. J Med Microbiol 2007; 56: 664-9.

13 Yakoob J, Hu GL, Fan XG et al. Diversity of Helicobacter pylori in Chinese persons with $H$. pylori infection. APMIS 2000; 108: 482-6.

14 Ikenoue T, Maeda S, Gura KO et al. Determination of Helicobacter pylori virulence by simple gene analysis of the cag pathogenicity island. Clin Diagn Lab Immunol 2001; 8: 181-6.

15 Tomb JF, White O, Kerlavage AR et al. The complete genome sequence of the gastric pathogen Helicobacter pylori. Nature 1997; 338: 539-47.

16 Covacci A, Rappuoli R. PCR amplification of gene sequences from Helicobacter pylori strains. In: Helicobacter pylori: techniques for clinical diagnosis and basic research. Philadelphia: WB Saunders, 1996: 94-109.

17 Abbas Z, Jafri W, Khan AH, Shah MA. Prevalence of Helicobacter pylori antibodies in endoscopy personnel and non-medical volunteers of Karachi. J Pak Med Assoc 1998; 48: 201-3.

18 Nizami SQ, Bhutta ZA, Weaver L, Preston T. Helicobacter pylori colonization in infants in a peri-urban community in Karachi, Pakistan. J Pediatr Gastroenterol Nutr 2005; 4: 191-4.

19 Kauser F, Khan AA, Hussain MA et al. The cag pathogenicity island of Helicobacter pylori is disrupted in the majority of patient isolates from different human populations. J Clin Microbiol 2004; 42: 5302-8.

20 Mukhopadhyay AK, Kersulyte D, Jeong JY et al. Distinctiveness of genotypes of Helicobacter pylori in Calcutta, India. J Bacteriol 2000; 182: 3219-27.

21 Blaser MJ. Role of vacA and the cagA locus of Helicobacter pylori in human disease. Aliment Pharmacol Ther 1996; 10 (Suppl 1): 73-8.

22 Jenks PJ, Megraud F, Labigne A. Clinical outcome after infection with Helicobacter pylori does not appear to be reliably predicted by the presence of any of the genes of the cag pathogenicity island. Gut 1998; 43: 752-8.

23 Kidd M, Lastovica A, Atherton J, Louw JA. Heterogeneity in the Helicobacter pylori genes vacA and cagA: associated with gastroduodenal disease in South Africa? Gut 1999; 45: 499-503. 